\title{
Aproximaçāo antropológica à atualidade da retórica
}

\section{Hans Blumenberg Traduçāo' de Luiz Costa Lima}

Inúmeros intuitos de definição foram feitos a propósito do homem. As variedades do que hoje se denomina antropologia filosófica são redutíveis a uma alternativa: o homem como uma criatura pobre ou rica. Não estar o homem fixado a uma certa ambiência pode ser compreendido como a carência fundamental de um equipamento ajustado à autoconservação ou como abertura para a plenitude de um mundo não mais tãosó organicamente acentuado. A urgência de suas necessidades faz o homem criador ou a relação lúdica com sua abundância de talentos. É ele a criatura incapaz de fazer gratuitamente alguma coisa ou o animal só capaz do acte gratuit. O homem é definido pelo que lhe falta ou que se aloja em mundos seus pelo simbolismo criador. É o expectador do universo no meio do mundo ou o excêntrico expulso do paraíso em um corpúsculo insignificante de terra. 0 homem abriga em si o produto estratificado de toda a realidade física ou é a criatura carente abandonada pela natureza, afligida por resíduos instintivos que se tornaram incompreensíveis e disfuncionais. Não preciso prosseguir com a enumeração das antíteses; vê-se com facilidade o princípio que nos permitiria ampliá-la.

No concernente à retórica, suas concepções básicas tradicionais permitem igualmente levar a uma alternativa: a retórica tem a ver com as consequências da posse da verdade ou com a perplexidade resultante da impossibilidade de alcançar a verdade. Platão conduziu a luta contra a retórica dos sofistas mediante o pressuposto que ela se baseava na tese da impossibilidade da verdade, de que derivava o direito de impôla à verdade. A retórica mais influente em nossa tradição, a de Cícero, parte ao contrário da posse possível da verdade, e dá à oratória a função de ornamentar a comunicação desta verdade,
1. Anthropologische Annäherung an die Aktualität der Rhetorik (1971). Republicado em: Ästhetische und metaphorogische Schriften. Frankfurt am Main: Suhrkamp Verlag, Tradução realizada sob supervisão de Doris Offerbach. 
em fazê-la acessível e expressiva, em suma: em processar a coisa de acordo com ela. A partir da premissa da posse da verdade, a tradição cristã oscila entre as duas possíveis consequências: por um lado, a verdade divina prescindiria da ajuda humana do modo retórico e deveria oferecer-se sem ornamentos - padrão que se repete em toda a retórica da sinceridade - e por outro lado mesmo esta verdade se humaniza no estuque canonizado das regras retóricas. Na estética dos tempos modernos, a implicação da retórica celebra seu último triunfo, tenha a ver positiva ou negativamente com a verdade, pela inversão da conexão: a partir da arte do discurso, do estilo, do belo, é permitida a dedução da verdade; arte e verdade se tornam idênticas. A inimizade que Platão estabelece entre filosofia e retórica está na própria filosofia, ao menos em sua linguagem, assim como está decidida a da estética contra a filosofia. Apenas como estética?

Vê-se com facilidade que ambas as alternativas radicais da antropologia e da retórica podem ser coordenadas entre si. Como criatura rica, o homem dispõe de sua posse da verdade com os meios eficazes do ornatus retórico. Como criatura pobre, o homem precisa da retórica como arte da aparência, que o ajusta à sua carência quanto à verdade. A situação epistemológica que Platão imputa à sofística, radicaliza-se antropologicamente na de "criatura carente". Ela faz tudo convergir à economia de seu instrumental de sobrevivência; que, em consequência, não podendo admitir a retórica, tenha de produzi-la. O agravamento antropológico das condições iniciais tem como consequência que também o conceito de uma retórica ajustado a elas deve ser compreendido de modo mais elementar. A técnica do discurso assim se mostra como o caso especial entre as maneiras reguladas de conduta que dá a entender alguma coisa, põe signos, produz persuasão ou provoca contradições. Um silêncio, uma omissão evidente, em um contexto comportamental podem se tornar tão retóricos como um grito de cólera do povo lido em uma folha de papel, e o diálogo platônico não é menos exposto à retórica do que uma lição sofística, contra a qual o diálogo arremete. A retórica, 
também sob o umbral da palavra escrita ou falada, da forma como meio, é regulamentada como porta-voz. Nietzsche estava errado ao estabelecer que a luta de Platão contra a retórica era de ser compreendido a partir da inveja por sua influência, mas tinha razão quando no mesmo lugar diz que os gregos teriam com a retórica inventado a "forma em si" (NIETZSCHE 1921, p. 105).

As duas grandes negações do platonismo, a atomística e a sofística, ainda eram mais consequentes do que as posições dogmáticas de sua constatável história dos efeitos conhecida como "platonismo". A preferência filosófica pela objetiva relação semântica da linguagem teve por consequência uma sensibilidade constante contra a compreensão linguística pragmática da retórica, que só episodicamente favoreceu a esta quando a linguagem conceitual, sob a modalidade da escolástica, foi objeto de consideração. A frase do Sócrates platônico, pertencente aos inventários culturais triviais, de que a virtude é saber, converte a evidência em vez da instituição em norma da conduta. Ninguém quererá negar que desta maneira formulava-se um ideal, logo seguido com arrogância e com desespero, sem a qual a tradição europeia não será pensada. Mas também vale que se constituía uma exigência demasiada a que logo se seguiu a resignação - a começar pelo retrocesso catastrófico que experimentou a doutrina das ideias da própria escola de Platão pela irrupção do ceticismo acadêmico apenas um século depois da morte de seu fundador e terminada com o que Nietzsche descreve como niilismo. A filosofia dos fins absolutos não legitima a teoria dos meios, senão que a recalca e estrangula. Uma ética que parte da evidência do bem, não dá espaço para a retórica como teoria e prática da influência exercida pelo comportamento sob o pressuposto de que a evidência do bem não é disponível. Isso também afeta a "antropologia" aplicada e aberta à retórica; a "antropologia", entendida como uma teoria do homem de que se retira a idealidade, abandonado pela evidência, perdeu a possibilidade de ser "filosófica" e se converte na última e retardada disciplina da filosofia. 
A significação antropológica da retórica destaca-se com preferência no pano de fundo da metafísica dominante desde a antiguidade, que tinha como base cosmológica que as ideias formam um cosmos, ao qual o mundo aparente reproduz. 0 homem também pode como expectador estar posto no meio do todo, mas não é nenhum caso particular senão que antes um ponto de intersecção de realidades estranhas, uma composição e, como tal, problemático. Do modelo estratificado modernizado permanece vivo o pensamento de que no homem se reuniram várias coisas que mal se toleram entre si. Esta metafísica sobretudo declara que os pensamentos do homem poderiam também ser de um deus e o que o move poderia mover uma esfera celeste ou um animal. Está-se diante de uma complicação da natureza, que antes apenas se representa e regula sem rodeios, que se deixa explicar como acidente ou mistura de elementos heterogêneos: o problema do comportamento então esteve em atribuir o domínio de um destes sobre os demais, em extrair uma espécie de consequência substancial. Em suma: sobre a afirmada unicidade do homem, a tradição metafísica fundamentalmente não tinha nada a dizer em particular. Isso é surpreendente mas se relaciona estreitamente com o repúdio filosófico da retórica. Pois a retórica parte daquilo e só daquilo que é singular ao homem e, com efeito, não porque a linguagem seria seu traço distintivo, senão porque a linguagem se indicia como função de uma perplexidade especificamente humana. Se se quiser expressar esta perplexidade na linguagem da metafísica tradicional há de se dizer que o homem não pertence a este cosmos (que então se lhe dá) - e, na verdade, não por conta de um excesso transcendental mas sim por efeito de uma carência imanente: da carência de estruturas de adaptação e regulação preparadas para uma conexão dignas do que se chama "cosmos', dentro do qual qualquer coisa devia ser chamada parte do cosmos. Também na linguagem da moderna antropologia biológica o homem é uma criatura que recai nos trabalhos de ordenação da natureza, cujas ações devem substituir as regulações que lhe faltam ou que devem corrigir as imprecisões erráticas admitidas. A ação é a compensação da "indeterminação" da criatura humana e a retórica é a produção 
cansativa daquelas concordâncias, que devem aparecer em lugar das funções "substanciais" nas regulações para que a ação se torne possível. Sob este aspecto, a linguagem não é um instrumental para a comunicação de conhecimentos ou de verdades senão que fundamentalmente a produção da compreensão, da concordância ou da tolerância visada pelo que age. Aqui se enraíza o consensus como base para o conceito do que "realmente" é: chamamos real aquilo de que todos estão convencidos, diz Aristóteles, e para isso sempre tinha no fundo um argumento teleológico. ${ }^{2}$ Só a destruição cética deste apoio tornou outra vez visível o subsolo do consensus.

Sei que hoje em dia o termo "cético" não é muito valorizado. Muitas coisas voltam a ser muito conhecidas e ninguém aprecia ser um estraga-festas. Mas a antropologia, cujo recalcamento metafísico procurei há pouco localizar, voltou-se em princípio para a tradição subterrânea do ceticismo, apenas ocasionalmente reavivada quando as verdades eternas tiveram de ser rebaixadas a afirmações mais seguras, mais próximas e o homem não mais se confundia com uma variante disfarçada de puro espírito. A primeira antropologia filosófica merecedora 36ss. deste nome é, no princípio dos tempos modernos, a "Apologie de Raymond Sebond" de Montaigne. Na mão de um cético que se vê impossibilitado de, a propósito do homem, perguntarse além dele, um material predominantemente convencional alcança um novo estado agregado, no qual o único objeto ainda possível ao homem decorre de que tudo ainda apenas é sintoma deste objeto. Pelos moralistas, esta tradição conduz ao que Kant expressivamente chamou de "antropologia".

O ceticismo amontado na porta das teorias do conhecimento (também da fenomenologia de Husserl), apenas visando sua liquidação definitiva, traz a oportunidade de seu rendimento antropológico, que depende da questão de que cabe ao homem ao lhe faltar acesso à pura evidência, à pura fundamentação absoluta. Prova deste estado de coisas é a maneira como Descartes não só liquida a dúvida teórica radical como também, com a então possível morale définitive, o problema da morale par provision, que devia vigorar até a 
perfeição do conhecimento teórico. A sempre instrutiva ilusão de Descartes não só consistia em que a morale définitive logo deveria se impor pois a física se desenvolveria com rapidez, mas sim antes que o entretempo poderia ser uma fase estática de manutenção do que desde sempre fora obrigatório. Descartes não reconhecia o retrocesso do processo teórico no suposto interim da moral provisória. É muito curioso pensar as consequências da ideia de uma morale par provision sob o pressuposto da ausente escatologia científica e daí reconhecer o que produzem para a comunidade as sempre frustradas expectativas definitivas da ciência. Ter Descartes querido encenar o provisório como pausa, o privava da necessidade de examinar a fundo as implicações antropológicas deste estado. Ele tomava como exemplo da moral provisória que aquele que se extraviara no bosque só precisava seguir uma direção pois todos os bosques têm um fim e para a situação pensada há de se considerar ser assim imutável. A recomendação da decisão formal para a moral provisória significa a interdição de levar em conta todos as características concretas da situação e de suas mudanças, com a inclusão da disposição do homem em um caso de orientação incerta. A anunciada utilização do "método" impede a autocompreensão atual do homem, também impede a retórica como uma técnica para dispor do provisório antes de todos as verdades e morais definitivas. A retórica cria instituições onde faltam evidências.

Poder-se-ia compreender o dualismo da filosofia com a retórica, cuja comparação sempre fracassou, por um certo conceito histórico-filosófico que converta o projeto de Descartes à medida que modifique ceticamente a morale par provision. Permanece duvidoso não só a plenitude do conhecimento científico, em qualquer âmbito, como também a contribuição possível de tal realização para uma morale définitive. É quase esquecido que o "progresso" não é senão o prolongamento da forma de vida daquele interim cartesiano, para que foi pensada a moral provisória. Onde Descartes tinha razão é que não há algo como uma participação provisória e de antemão concedida no resultado do todo. Dito de outro modo: ganhe ou perca o 
programa da filosofia, ela não provoca nenhuma contribuição a prazo. É retórica tudo que está além da evidência; ela é o órgão da morale par provision. Antes de tudo, tal constatação significa que a retórica, em seu núcleo, é um meio legítimo. A retórica é um sintoma dos pressupostos céticos. Não se deve esquecer que ela poderia apenas se opor ao veredito de ser um "puro meio", à medida que se apresenta como o meio da verdade. Pois ainda em suas vitórias a retórica deve proceder "retoricamente": quando no século IV a.C. a retórica foi afastada das reivindicações filosóficas, Isócrates chamou sua sofística pelo artifício de "filosofia". Para Jacob Burckhardt, o sentido que tinham os gregos para eficácia, em vez de realidade, é a base da retórica, que só por momentos se erigia em oratória pública, de resto formada a partir do êxito nos tribunais. Mas para os próprios gregos a persuasão se punha em oposição à violência: segundo Isócrates, no trato dos gregos com os gregos, a persuasão é apropriada, no trato com os bárbaros, cabe o uso do poder; mas esta diferença era compreendida como da língua e da cultura, porquanto persuasão pressupõe um mesmo horizonte, a alusão ao prototípico, à orientação pela metáfora, pela comparação. A antítese entre verdade e efeito é superficial, pois a eficácia retórica não é a alternativa elegível para uma compreensão, que também poderia recorrer, senão à evidência, que não se pode ou ainda não se pode ter aqui e agora. Assim a retórica não é tão-só a técnica cuja eficácia se pode obter, mas sempre e também algo para alcançá-la: ela torna consciente o meio eficaz, cujo uso não precisa ser propriamente prescrito, pois ela explicita o que também já estará feito.

Enquanto a filosofia quis dispor, ao menos ter em vista, verdades eternas, conhecimentos definitivos, devia-lhe ser abominável o consensus como ideal da retórica, a concordância como resultado alcançável pela persuasão. Mas com sua transformação nos tempos modernos em uma teoria dos "métodos" científicos, não se poupou a filosofia a renúncia a tudo que toca a retórica. Na verdade, a princípio parecia que as hipóteses da ciência sempre fossem meios provisórios a favor 
do conhecimento, disposições para levar a cabo a verificação e assim a certeza definitiva; mas a história da ciência elucidou que também a verificação representa o tipo de concordância frente à contestação, que a publicação de cada teoria implica um apelo a prosseguir nos caminhos indicados de sua convalidação que se the indicam para alcançar a resolução da objetividade, sem a qual este processo nunca pode ser concluído, que outros caminhos serão achados e contradições exigidas. $O$ que Thomas S. Kuhn chamou de paradigma em seu $A$ estrutura das revoluções científicas (KUHN 1962) - a concepção dominante por um longo período em uma disciplina científica, integradora de todas as pesquisas posteriores que a refinam e ampliam - não é senão um consensus que se estabilizou, se bem que não exclusivamente, mas também com a ajuda da retórica das academias e dos manuais.

Conquanto a falta de evidência possa ser a situação comum entre o processo teórico e a retórica, a ciência conta com a incalculável vantagem de poder suportar a provisoriedade de seus resultados. Mas sua representação do "método" possibilita compreender e organizar a ciência como um processo total integrante, constantemente "transferível", que tem os indivíduos e as gerações tão-só como funcionários. Toda ação que se apoie como "aplicação" nesta ideia de teoria deve compartilhar da debilidade de sua provisoriedade, a qualquer momento passível de divergência. Também as teorias implicitamente solicitam "concordância" como a retórica o faz explicitamente. A diferença decisiva está na dimensão do tempo; a ciência pode aguardar ou pode manter-se sob a convenção, enquanto a retórica como elemento constitutivo pressupõe a compulsão à ação da criatura carente - quando não mais possa ser ornatus de uma verdade. É por isso uma reprodução da forma processual da ciência quando a discussão tem o papel de servir de instrumento para a formação pública da vontade como um mecanismo para encontrar resultados racionais, enquanto, ao contrário não pode cumprir a ilimitação principal da racionalidade científica. O tempo de fala restrito do orador pode haver substituído insuficientemente o rigor 
das prescrições formais da retórica mas, como substitutivo, é também uma instituição essencial da retórica; onde ele é descurado ou é ignorado ou se torna o oposto institucionalizado (o trapaceiro), converte-se na manifestação do caráter de alternativa ao terror, de que dispõe a retórica. Sob o aspecto da retórica compreende-se estar consciente da compulsão à ação, assim como do âmbito da norma em uma situação finita. Tudo que aqui não é coação, prospera como retórica e a retórica implica a recusa à coação.

A compulsão à ação determinada pela situação retórica e que fundamentalmente impõe uma reação física é retoricamente transformada de modo que a ação coagida torna-se outra vez pelo consensus em "apenas" retórica. Substitui as operações físicas pelas verbais é um radical antropológico; a retórica o sistematiza. Em sua Philosophie der symbolischen Formen, Ernst Cassirer descreveu o homem como o animal symbolicum cuja produção originária é transformar a "impressão" externa em "expressão" do interno, convertendo deste modo algo estranho e inalcançável em algo sensivelmente apreensível. A linguagem, o mito, a arte e a ciência são, conforme Cassirer, regiões de tais formas simbólicas, que, em princípio, repetem aquele processo primário de substituição da "impressão" em "expressão". Mas esta teoria de Cassirer renuncia a explicar por que se exigem as "formas simbólicas"; o fato de que apareçam no mundo da cultura admite que a chave esteja no animal symbolicum, cuja "natureza" se manifesta em suas criações. Uma antropologia do homem "rico" faz crescer progressivamente a base de uma existência biológica segura, pelo menos inquestionada camada por camada o invólucro cultural das "formas simbólicas". A concentração da existência desnuda não tem nenhuma relação funcional com sua possibilidade de existência. Mas à medida que a filosofia seja a desmontagem do que se tem por evidente, uma "antropologia filosófica" tem de tematizar que a existência física não é o mero resultado daquelas operações atribuídas ao homem como "essenciais". O primeiro enunciado de uma antropologia seria então: não é evidente por si que o homem possa existir. $O$ tipo de tal reflexão está pré-formado na 
teoria moderna do contrato social, que deduz a necessidade de fundamentação da condição burguesa do homem do encontro, na situação "natural", de uma contradição entre as condições de possibilidade da existência física. Em Hobbes, o Estado é o primeiro artefato que não enriquece a esfera da vida com vistas a um mundo da cultura senão que contorna aquele antagonismo mortal. Filosoficamente, não é fundamental nesta teoria que explique a produção de uma instituição como Estado - e ademais absolutista - senão que transfere a hipotética determinação da essência do homem como "zoon politikon" para uma representação funcional. Não vejo nenhum outro traçado científico para uma antropologia senão analogamente destruir a suposta "naturalidade" e transportar sua "artificialidade" no sistema funcional da operação elementar da "vida" humana. Paul Alsberg empreendeu em 1922 uma primeira investigação a propósito, mas, prejudicado por seu título, Das Menschenrätsel (O enigma humano), seu livro foi pouco notado. Em 1940, Arnold Gehlen, com a obra fundamental, embora questionável em sua intenção, Der Mensch (O Homem) desenvolveu o princípio de uma teoria da percepção e da linguagem, desde então prolongada com a consolidação da teoria da "instituição". Com o absolutismo das "instituições" de Gehlen. A antropologia de certa maneira retorna a seu ponto de partida com o modelo do contrato social. Até hoje a discussão sobre esta antropologia não esclareceu se esse fatídico retorno não era inevitável.

A carência do homem em dispositivos específicos para um comportamento reativo frente à realidade, assim sua pobreza de instintos é o ponto de partida da questão antropológica central: como esta criatura pode existir apesar de sua insuficiência biológica. A resposta pode ser assim formulada: à medida que não se encaixa imediatamente nesta realidade. A relação do homem com a realidade é indireta, circunstancial, diferida, seletiva e, antes de tudo, "metafórica". A interpretação nominalista do julgamento há muito tempo nos mostrou como o homem, com o excesso de demandas, estabelece suas relações com a realidade. Os predicados são "instituições"; algo concreto é apanhado porquanto se desliga 
de sua pertença a estas instituições. Quando emergem em julgamentos, como concreção os predicados desaparecem. Mas captar algo como algo difere radicalmente do procedimento de captar algo por meio de outra. O rodeio metafórico de encarar um outro objeto a partir do objeto temático, supõe, de antemão, ser uma operação instrutiva, trata o dado como o estranho e o outro como o disponível confiável e manejável. A identidade é o valor limite do julgamento, assim o valor limite da metáfora é o símbolo; aqui, o outro é o completamente outro, que não dá mais do que a pura substituibilidade do indisponível pelo disponível. O animal symbolicum domina a realidade para ele genuinamente mortífera à medida que a deixa representá-lo; afasta o que lhe é estranho em favor do que lhe é familiar. Isso é mais patente ali onde o julgamento com sua exigência de identidade não consegue alcançar seu alvo, seja porque seu objeto vai além do procedimento (o "mundo", a "vida", a "história", a "consciência") seja porque o espaço de manobra do procedimento não é suficiente, como em situações de compulsão à ação em que são necessárias uma rápida orientação e uma drástica plausibilidade. A metáfora não é apenas um capítulo no tratamento do meio retórico, ela é o elemento significante da retórica, em que se apresenta sua função e se pode remeter sua relação antropológica.

Seria bastante unilateral e incompleto apresentar a retórica apenas como a "solução de emergência" face à carência de evidência em situações de compulsão à ação. Ela não só substitui a orientação teórica para a ação; é mais significativo que possa substituir a própria ação. O ser humano não só pode representar uma coisa em vez da outra senão que também pode fazer uma em vez da outra. Se, em suma, a história ensina alguma coisa é esta: sem a capacidade de substituir ações não haveria muito da humanidade. A representação ritualizada da vítima humana através de uma vítima animal, tal como ainda transparece na história de Abraão e Isaac, pode haver sido um princípio. O cristianismo manteve por dois mil anos como muito evidente que a morte de um demonstrava a desgraça culpada de todos. Freud via na refeição fúnebre a 
convenção dos filhos que visava a dar fim ao assassinato do pai da horda e, em vez disso, fazer algo diferente. Antes da viagem de 1909 à América, Freud, em Bremen, persuadia C. G. Jung, o discípulo suspeitoso de traição, a beber vinho enquanto comia - o que transgredia os princípios fundamentais de seu primeiro mestre, Bleuler -, em vez de obrigá-lo a um ato de submissão, por não querer ser ele próprio desempenhar o papel de pai. Há em política a censura de que o ato verbal ou demonstrativo é mais sério do que a "pura retórica"; mas o mesmo argumento cabe à retórica que não quer crer e tampouco precisa crer que uma política é tanto melhor quanto mais produz e não se limita a "meras palavras". Em política externa, são frequentes as advertências que continuam a ser emitidas antes que o cumprimento do ato para o qual se advertia tenha sido alcançado. Tudo depende - como se costuma dizer - de "limitar-se a declarações", de dissuadir a compulsão à ação se o risco da mesma poder desqualificar todo êxito possível. Entram aqui em jogo questões sobre o conceito de realidade que não podem ser tratadas neste contexto.

A falta de evidência e a compulsão à ação são os pressupostos da situação retórica. Mas o retórico não é só o procedimento substitutivo e metafórico. A própria compulsão não é um fator completamente "real", pois também se baseia no "papel" atribuído ao agente ou com quem ele mesmo procura se definir - também a autocompreensão serve-se do metafórico e "persuadir-se a si próprio é um rodeio que trai que o uso interno da retórica não é nenhum novo descobrimento. A metafórica do papel, hoje de novo em curso, baseia-se na muito sólida tradição que implica ver a vida e o mundo como "teatro", sem que em todas as formas históricas de teatro se entenda que seus "papéis" sejam fixados, como hoje pressupomos quanto ao uso da metáfora. Permitir a alguém no decurso de um conflito que "livre sua cara", decorre na verdade de um outro campo discursivo, mas encobre amplamente o imperativo implícito na metafórica dos papéis de que não se escuse à pessoa de referência, obrigada em um acontecimento a esta alteração de conduta, a sair de seu papel, mas sim que apresente a 
exigida mudança como consequência verossímil. Não preciso aqui ilustrar em que medida a política das grandes e pequenas potências pode ser descrita como definição e expectativa de papéis (aqui outra vez se toma a metáfora como metáfora antropológica) e de quais indicações pragmáticas para tratar de um procedimento que, potencialmente retórico, assim de fato se torna, estão aqui implicadas. Georg Simmel a respeito assinalou que a metáfora de papéis é tão produtiva porque a vida é uma "forma preliminar da arte teatral"; com a afirmação, Simmel reconhecia que esta metafórica não está mais associada ao pressuposto de que se trata de ilusão, da dupla vida encenada com ou sem máscara, com ou sem disfarces, de maneira que apenas bastaria privar-se do palco e dos atores para ver-se a realidade; para acabar com o intermezzo teatral. A "vida" de que Simmel fala não é uma forma preliminar próxima e vizinha da arte teatral senão que são idênticos poder viver e definirse um papel. $O$ que afirmo é que esta afirmação dos papéis não só é metafórica senão que o próprio processo definitório do conceito de papéis - de que depende a consciência de identidade e com o qual ela pode ser ferida - se enraíza na metáfora, afirma-se e defende-se interna e externamente de maneira metafórica. A própria circunstância de defendêlo torna-se significativo: o livro Estigma (1963) de Erving Goffman em muito contribui para isso. Que a concordância deva ser o alvo da "persuasão" (mesmo da autopersuasão) é a congruência sempre ameaçada e outra vez reiterada pela consciência e expectativa de papéis por parte dos outros. Talvez "concordância" seja um termo demasiado forte e a aprovação sempre se dê em um momento excepcional. Trata-se no fundo de não se encontrar contradição alguma, tanto no sentido interno da consistência como no sentido externo de aceitação. A retórica não é apenas um sistema, um mandato que requer ação, senão uma compreensão configurada e configurante que se afirma a si e perante os outros e que se há defender. Do ponto de vista da teoria da ciência, o "papel" metaforicamente concebido ocupa a função de uma hipótese, que "verifica" cada ato que não falsifica. O resto do valor teleológico do consensus, mantido para toda retórica como salvaguarda da natureza, é 
a garantia da não contradição, da não ruptura da consistência do aceito, o que no jargão político diário é por isso chamado de "plataforma". Face a este resultado é compreensível que a obrigação face à "base da convicção comum, formulada por propostas sempre diversas, se torne virulenta. Pode-se portanto chamar o consensus de uma "ideia" do efeito retórico; na fundamentação antropológica, a função retórica é redundante.

A substituição retórica na compulsão à ação e a proteção retórica da auto-representação como "autoconservação" têm em comum pressupor, de fato, atos criativos (criação de símbolo, concepção de papéis), mas que, na pura criatividade, permanecem impotentes e disfuncionais. Aqui ao mesmo tempo se põe a pergunta se a conexão entre as estéticas da produção e da recepção não leva a uma estrutura análoga. Cada arte tem um grau de retórica, escreve Nietzsche, em 1874, em um fragmento sobre Cícero (NIETZSCHE 1923, p. 385). A "invenção" do símbolo substitutivo é o ato mais inofensivo e mais imaginativo do mundo. Tem de ser reconhecido e para isso, ao contrário da obra estética, não contém materialmente o mínimo atrativo. Mas este reconhecimento é aqui tão valioso como tudo; só ele tem consequências. Lembro a fórmula política clássica: o comércio segue a bandeira; hoje pode-se dizer ao contrário: a bandeira segue o comércio (Estados que sequer mantêm relações diplomáticas estabelecem tratados comerciais na expectativa de que outros se sigam) - a inversão da velha frase exprime a plena desvalorização do símbolo da bandeira, que ainda tão-só ornamentam a realidade. Dizer que o valor das substituições se baseia na convenção é tão certo quanto tautológico. A convenção é um resultado - como se verifica? Por certo, por oferta e publicidade. Isso vale inclusive para o caso abstrato da história da ciência, em que se impõem os sistemas simbólicos da lógica formal. A retórica publicitária detalha ou consiste em pretender publicamente inacreditáveis formas nacionais que nunca podem ser compreendidas. Quanto menos realidades políticas ainda podem ser "criadas" fora da esfera econômica, tanto mais importante se tornam "reconhecimentos", questões de intitulação, tratados, nos quais 
de todo modo se renuncia ao impossível, aos procedimentos em que se discute duramente sobre o, de qualquer maneira, já está estabilizado. Tão logo não há mais o que valia como "real" as próprias substituições se convertem em "o real". Na estética, com o abandono de todos os modos e graus de objetividade, só com o grande dispêndio de retórica, impõe-se a oferta de aceitar algo como obra de arte ou também o que é "exigível" depois do fim de toda arte. Não se trata fundamentalmente da obrigação de comentário de uma obra, do que se faz valer nos textos que a acompanham ou a seguem mas sim de sua declaração que estamos diante de uma obra de arte ou do que veio depois; a propósito, a crítica feroz de um crítico competente sempre ainda produz aceitação no contexto de uma história em que uma modalidade de arte sempre se fez contra outra modalidade - com o gesto retórico de dar fim ao conhecido e começar o que se lhe segue. Também a negação da retórica ainda é retórica; mesmo o ponta-pé que recebe o expectador na "compreensão" convencional the demonstra que o que antes não compreendia tem seu "lugar" ocupado ou que agora compreenderá a instância competente. O "reinvestimento" em que consiste a história, cumpre-se retoricamente.

A retórica também tem a ver com a estrutura temporal das ações. Aceleração e retardo são momentos dos processos históricos, que até hoje têm merecido pouca atenção. A história não consiste apenas em acontecimentos e (como sempre se entendeu) em sua articulação, mas também no que se poderia chamar seu "conglomerado" temporal. O que em nossa tradição é descrito como racionalidade quase sempre favoreceu o momento de aceleração e condensação dos processos. Mesmo as teorias dialéticas da história acentuam os fatores de aceleração porque impulsionam o processo ao ponto crítico de mudança repentina e assim torna reconhecível o estágio final, e aproxima das disposições legais afirmadas. O fenômeno multiestratificado da tecnologização se reduz à intenção de ganho de tempo. A teórica ao invés é, em face da estrutura temporal das ações, um núcleo dilatório. O detalhamento, a fantasia processual, a ritualização implicam a dúvida de 
que a ligação mais curta entre dois pontos também seja o caminho humano. Esteticamente,. Por exemplo na música, esta situação nos é bastante familiar. No mundo moderno, as pretensões exageradas não só decorrem da complexidade das situações como também da divergência crescente entre as duas esferas das exigências objetivas e das decisões relativas à sua estrutura temporal. Deu-se um desentendimento entre a aceleração dos processos e as possibilidades de manejálos com as decisões de neles intervir e coordená-los com outros processos. Certas funções auxiliares que podem ser exercidas para a ação humana têm um efeito assimilador: onde todos os dados são rapidamente disponíveis, a decisão rápida parece ser a evidência adequada. A vontade de manter o desenvolvimento em mãos e assim mantê-lo comanda as considerações acerca da crítica ao progresso, à medida que elas não são puro romantismo. Análises operacionais fornecem ótimas soluções de problemas, mas não dissipam a dúvida de se o problema foi bem posto - e esta dúvida já caracteriza a ação como o que pressupõe sua teoria e como o que não é mero resultado da teoria. Na ação pública, reconhece-se distintamente o forte cunho dos momentos de retardo. Não por acaso uma palavra gasta como "reflexão" volta a ser uma palavra na moda. Há uma necessidade institucional de dar um suspiro forte que faz com que também maiorias de capacidade decisiva dêem grandes rodeios retóricos. Deve-se considerar que não se é "impulsionado" (por qualquer coisa que seja) e que não se pensa em meramente sancionar o decidido há muito tempo. A aceleração do processo é apenas uma variante daquela "inundação de excitações" que é constitutiva da criatura biologicamente pobre que é o homem e que se encontra com a institucionalização de sua conduta. Instituições verbais não são de modo algum um grau de atrofia das regulações maciças; seu poder deve ser medido pelo ideal das teorias decisionistas, ideal consistente na pontualidade.

Há como que uma oportunidade no inoportuno. Observamos hoje em dia uma desmontagem vertiginosa de formas "antiquadas" por meio de procedimentos críticos em 
que o peso de justificação de sua existência recai sobre todo o existente; mas vemos ao mesmo tempo uma exuberante fantasia na reconfiguração de procedimentos muito detalhados, que só se distinguem por denominações bem prosaicas, como regulamentos internos, órgãos de controle, sistemas de funcionamento. Cada ganho de tempo é de todo consumido.

Devemos progressivamente abandonar o pensamento de um tipo de formação comandado pela norma de que a criatura humana deve em cada momento saber o que faz. Um médico deveria conhecer não só as condições de funcionamento dos órgãos, cuja falência provoca as doenças e assim o modo de atuar das terapias e dos remédios que prescreve, como ainda dominar as palavras estrangeiras de que precisa constantemente para designar tudo isso e cujo emprego the assegura ser depois consagrado. Um capitão não deveria poder apenas usar o sextante e as fórmulas pertinentes de trigonometria, mas também saber como o instrumento funciona e como as fórmulas podem ser deduzidas. Desta maneira ele seria um Robinson potencial, que poderia começar do nada se estivessem perdidos os meios de ajuda pré-fabricados. Frente a isso, há muito ganha terreno o pensamento de que o mundo técnico precisa de funcionários treinados, com reações apropriadas mas não que compreendam todas as conexões de funcionamento. Sempre menos pessoas ao aprender o quê fazem saberão porquê o fazem. A ação se atrofia em reação quanto mais se procura um caminho direto entre a teoria e a prática. O clamor pela eliminação do aprendizado de matéria "inútil" é sempre pela transformação funcional em prol do "mais leve". Na verdade, a complexidade da exigência de saber o que se faz ainda não é garantia de uma compreensão humana ou moral, mas sim um tipo de reação diferida de uma ação potencialmente "consciente". Suponho que a "cultura" - seja o que possa ser - tem a ver com este diferimento das conexões funcionais entre sinais e reações. Com o quê seus conteúdos, seus "valores" e "materiais" se tornam secundários. A discussão sobre estes valores é sobretudo conduzida com uma distribuição de asserções não comprovadas: quem defende 
bens culturais transmitidos deve provar que ainda têm valor. Supondo que já não tenham valor algum, se mostra evidente seu caráter retórico: são figuras, exercícios obrigatórios, rodeios e complicações obrigatórios, rituais que dificultam ao homem o aproveitamento imediato, que bloqueiam o início de um mundo de ligação mais curta entre dois pontos ou apenas o retardam. A retórica clássica essencialmente visa ao mandato para a ação; a retórica moderna se empenha no diferimento da ação ou ao menos para a compreensão deste e isso também quando quer demonstrar a capacidade de ação, à medida que outra vez mostra as substituições simbólicas.

O princípio fundamental de toda retórica é o princípio da razão insuficiente (principium rationis insufficientis). É ele o correlato da antropologia de uma criatura a que falta o essencial. Se o mundo dos homens correspondesse ao otimismo da metafísica de Leibniz, que acreditava poder indicar o fundamento suficiente para o fato de que algo existe e não o nada (cur aliquid potius quam nihil), não haveria nenhuma retórica pois não haveria nem a necessidade, nem a possibilidade de, por ela, provocar efeitos. Já a difusão da retórica mais significativa de nossa história, a da oração, devia dirigir-se a um Deus que devia deixar-se persuadir, ao contrário das posições teológicas do conceito racionalista ou voluntarista de Deus; este problema é reiterado pela antropologia: o homem tematizado por ela não se caracteriza pela superação filosófica da "opinião" através do saber.

O princípio da razão insuficiente contudo não se confunde com o postulado de renúncia à razão, assim como a opinião não designa a conduta infundada senão que a difusa e não metodicamente regulamentada. Deve-se ter prudência com a censura de irracionalidade quando se devam excluir procedimentos indefiníveis, indetermináveis e amplos; no campo de fundamentação da práxis da vida o procedimento insuficiente pode ser mais racional do que a insistência nos de "aparência científica" e ser mais racional do que o disfarce de decisões tomadas com raciocínios tipificados como científicos. A euforia face ao assessoramento da ciência a ações públicas é, com efeito, algo decrescente, mas as desilusões quanto a esta união 
se baseiam na visão errada de que as associações de cientistas, na falta de evidência conclusiva em seus conhecimentos, não podem senão proceder como instituições que os aconselha retoricamente, ou seja, tendo por alvo um consensus fáctico, que não pode ser o consensus de suas normas teóricas. A norma científica também a clara caracterização de uma modalidade de enunciado. Afirmar apoditicamente ou assertoricamente o que só podia ser afirmado problematicamente transgride a norma. Quem é afetado pela ação pública ou quem a acatou deve exigir saber que dignidade têm os pressupostos que se passam como resultado do assessoramento científico. A retórica ensina a reconhecer a retórica, mas não ensina a legitimá-la.

Não se trata apenas da relação entre ciência e instâncias políticas senão também de um âmbito de enunciados de efeitos práticos muito significativos e não permanentes que, de acordo com seu status teórico, sempre têm uma fundamentação insuficiente ou são inverificáveis. A proposta positivista de extirpar questões e enunciados que não contêm elementos para sua verificação implica a paralização da práxis fundada em tais premissas e assim se torna ilusória. Científica mas não praticamente, pode-se adiar ou declarar sem sentido a decisão de questões como, por exemplo, se o homem é por natureza bom ou mau, determinado por sua constituição ou por seu ambiente, se é condicionado ou condicionante de sua história. Assim como todo tipo de pedagogia já se encontra no processo prático e não pode esperar que se lhe forneçam seus pressupostos teóricos; daí que a pedagogia seja forçada a aceitar o quase resultado da oferta das generalizações teóricas da biologia, da psicologia, da sociologia e de outras disciplinas. Nesta zona limite, sucedem curiosos processos de tipo do retórico, nos quais racionalidade e realismo parecem divergir; pois aqui não há apenas compulsão à ação como tal mas sim a necessidade de axiomatização de pressupostos, sem a qual a teoria relacionada às compulsões à ação seriam paralisadas e condenadas à esterilidade. Penso no entanto que tais decisões não têm nada a ver com o cinismo de uma liberum arbitrium indifferentiae e muito menos com o 
autoposicionamento existencialista.

No âmbito de validade do princípio da razão insuficiente há regras de decisão racional que não têm uma constituição científica. Com seu argument du pari (argumento da aposta), Pascal deu um modelo que só não nos é bastante porque compara o risco de uma aposta finita com a oportunidade de um ganho transcendental infinito, mas que permanece válido ao declarar que o homem, ante qualquer risco de erro, deve dispor da aposta de sua práxis pela alternativa teórica favorável à sua autoafirmação e autodesdobramento. Qualquer dúvida teórica sobre a validez do princípio da causalidade ou de sua fundamentação evidente pode alterar dispormos da validez inesgotável de nosso comportamento. Um dos enunciados mais fecundos no âmbito de diversas ciências seria a resposta à questão sobre em que medida os modos de conduta do homem são determinados ou daí influenciados por fatores endógenos ou exógenos. Ainda que se possa considerar esta questão complexa como cientificamente não decidida, é fácil reconhecer que reflexões teórico-científicas favorecem o determinismo endógeno, assim como, na teoria da evolução, com independência dos achados empíricos, implicam a preferência pelo darwinismo às espécies de lamarckismo. A teoria que se limite a apresentar fatores especificamente poucos, metódica e nitidamente isoláveis, tem maiores chances de se tornar um "paradigma, no sentido de Thomas S. Kuhn, do que aquela que tenha de oferecer um conglomerado preparado de fatores difusos. A aproximação científica a um resultado do tipo da teoria darwinista pareceme inevitável e teoricamente fundada.

Este desenvolvimento deveria ter amplas consequências em vários campos das vidas pública e privada: para a educação e a jurisprudência, para a profilaxia social e para o cumprimento das penas, assim como para o convício diário entre os homens. Mas de fato parece que a prioridade dos axiomas práticos não parece se orientar pela dominância científica. É esta a situação descoberta por Kant quando, na doutrina dos "postulados" de sua Crítica da razão prática, admite a independência das decisões morais das demonstrações teóricas. Para Kant, são 
as proposições clássicas de toda metafísica - a liberdade do homem, a existência de Deus, a imortalidade - que se unem inseparavelmente, em forma de postulado, à lei prática. A lógica desta inseparabilidade se torna patente se se observa que apenas quem transgride a lei tem interesse em alegar sua falta de liberdade e a inutilidade do comportamento legal quanto ao bem-estar. Teríamos de retirar os postulados de toda metafísica para conectarem-se os postulados da retórica à moral: eles seriam um conjunto constitutivo do consensus de axiomas práticos através da persuasão e da autopersuasão que propicia o assentimento a esforços públicos e privados e dá sentido, as condições para a vida livre de delitos e conflitos e de ter confiança na admissão de currículos antiquados ou desarticulados. Assim fazemos "como se" soubéssemos que esforços e gestos desta natureza em prol do homem não são inúteis e não serão questionados pela ciência. A práxis axiomatiza como "postulados" o que motiva perceber as grandes oportunidades humanas. A retórica é também aqui a arte de não levar em conta a persuasão do que se opõe à aposta nestas oportunidades. Os resultados frustrantes da pesquisa genética dos gêmeos não devem poder, e com razão, desanimar os defensores das teorias do meio. Por maior que seja a insegurança dos enunciados científicos, nunca será admissível e tolerável uma teoria sem práxis Desde Kant, o postulado prático se erige contra o determinismo subjugante do mundo de objetos científicos possíveis.

A retórica não tem a ver com fatos senão que com expectativas. Aquilo que em toda sua tradição foi denominado "crível" e "equivalente à verdade" em sua capacidade prática deve ser claramente diferenciado do que teoricamente se chama "verossímil"3. Que o homem "faz" a história é uma oportunidade posta pelos tempos modernos depois de rodeios histórico-filosóficos. Esta frase só pode ser compreendida se se percebe o remanejamento por ela empreendido. Introduzi e expliquei este conceito no meu Legitimität der Neuzeit (Legitimidade dos tempos modernos, 1966), mas ainda não via que implicava um processo teórico. Pois assim não se descobre 
ou compreende quem é o sujeito ativo da história; o sujeito da história é "nomeado". No sistema de explicação da realidade de nossa tradição já se refere um "lugar" para o sujeito da história como vazio ou ocupado. A imposição e a confirmação do remanejamento são atos retóricos; a "filosofia da história" apenas tematiza a estrutura deste, não a traz consigo. Não é acidental que o ato pelo qual o sujeito da história é determinado e legitimado traga o nome de uma figura retórica fundadora: translatio imperii. As "transposições", as figuras metafóricas aqui desempenham um papel essencial. Alexandre empunha sua concepção histórica na inversão do caminho de Xerxes para o Helesponto. O Deus do Antigo testamento transfere sua soberania da história por um contrato. Os cidadãos da Assembleia da Revolução Francesa tomam ao pé da letra, com trajes e frases, a metafórica da república romana. Os homens fazer sua própria história, mas não a fazem por decisão livre, nem por escolha própria senão que circunstâncias de antemão encontradas, dadas e transmitidas, escreve Marx no 18 Brumário (MARX; ENGELS 1960, p. 115). Quanto mais profunda alcança a crise de legitimidade, tanto mais marcado é o recurso à metafórica retórica - a tradição não é feita pela preguiça mas sim pelo embaraço em satisfazer a designação do sujeito da história. Daí que seja mais fácil contentar-se com a participação no papel de sujeito da história: não se é, mas se participa disso, tal afirmação deveria ser incluída se as coisas fossem como deveriam ser. Na retórica, estão igualmente disponíveis as justificações como as desculpas.

A retórica não é aqui consagrada como um talento criativo do homem. Sua elucidação antropológica não é a demonstração de um "privilégio metafísico". Como evidência de comportamento de uma criatura que apesar de tudo vive, é, no sentido da palavra, um "testemunho de pobreza". Temeria chamá-la de "astúcia da razão" não só porque ainda a vejo em companhias duvidosas mas porque gostaria de registrar e de nela ver a própria configuração da racionalidade, um arranjo com a provisoriedade da razão. Pode ser que a provisoriedade teórica que ela percebe e utiliza seja para ela mesma apenas 
um prazo de graça, se não for justo que não há irrevogabilidade teórica. Contra toda retórica que não é a clara e elegante expressão dos pensamentos e conceitos, Hobbes recomendava o emprego da "justa razão". Esta expressão é semelhante a "razão crítica", atualmente em curso. Está bem dito, mas quem poderia julgar se se trata, em cada caso, da razão "justa", salvo a razão e, de fato, a razão "verdadeira"? Para Hobbes, é uma das objeções mais importantes contra a democracia, pois ela não poderia avançar sem retórica, porquanto seus oradores não se orientam pela "natureza das coisas" mas sim pelas paixões de seus ouvintes. Esta não é uma falta dos homens mas sim da eloquência, cuja meta, como ensinam todos seus professores, não é a verdade (exceto ocasionalmente) mas sim a vitória, e cuja tarefa não é ensinar mas persuadir. ${ }^{4}$ Uma frase curiosa que expressamente considera os homens livres dos efeitos de um instrumento porque o inventaram e usam. Uma frase estranha só correta se é confrontada com o tipo de racionalidade que a teoria do Estado de Hobbes representa: a autoconservação como motivação racional do contrato de submissão arriscase ante a vontade indeterminada e indeterminável do senhor absoluto àquele impetus animi, que Hobbes discrimina como correlato da retórica.

A patologia da retórica por Hobbes reconduz a excitação das paixões ao uso metafórico das palavras. Também para ele a metafórica é o elemento significante da retórica; ele a considera ajustada às paixões e assim distanciada do verdadeiro conhecimento das coisas (HOBBES De cive X, 12). Em que se baseia a conexão entre metafórica e paixão, que Hobbes supõe evidente por si mesma? Para ele, a metafórica é o oposto do conceito: à medida que exclui o instrumental da razão, ela estabelece o campo livre para tudo que, segundo a tradição, é freado e controlado pela razão, para o que se afasta do esforço do conceito pela orientação imaginosa. Hobbes aqui considera valer uma eloquentia que contém a metáfora e, provinda da observação das próprias coisas, consiste apenas na elegância de exposição de conhecimentos. Confrontada com a "natureza das coisas" como possível de ser possuída, a retórica 
realmente aparece como um meio artificial excêntrico. É certo que se assim se observa a teoria do conceito de Hobbes é surpreendente que sua recusa da metáfora consiste em confiar na razão humana mais do que ele próprio admitia na teoria do conceito. Pois também o conceito é um meio artificial que nada tem em comum com aquela "natureza das coisas". Não é acidental que se ponha o dedo nesta discrepância na crítica da metáfora como o elemento essencial da retórica. A discrepância motiva a hipótese que a crítica à metáfora pela recorrência à sua afinidade com as paixões se funda na contradição da ideia do Estado absoluto com uma retórica, descrita como o atributo necessário do homem nascido para a intranquilidade. Ora, de fato, a metáfora não é um sucedâneo de um conceito em falta mas sempre possível e por isso requerível, senão que um elemento projetivo que tanto amplia como ocupa o espaço vazio, um procedimento imaginativo que cria na semelhança sua própria consistência. Como Ahlrich Meyer rapidamente mostrou (MEYER 1969, p. 128-199), o Estado absoluto é deduzido do princípio da autoconservação, entre, de um lado, as tenazes da metafórica do orgânico e, de outro, do mecanismo. Tal metafórica axial tem sua própria força de persuasão, que remete precisamente ao núcleo metafórico das ampliações possíveis: a possibilidade de uma história da filosofia orgânica fortalece por exemplo o tipo do Estado orgânico; o próprio Hobbes passou por cima da contradição entre sua metafórica orgânica para a "pessoa do Estado" pela artificialidade de sua origem - e isso é bastante instrutivo, pois o veredito contra a metáfora dificulta a percepção de sua função fáctica pressuposta. Mesma a interdição da retórica é um precedente retórico que só os outros percebem como tal. O exemplo de Hobbes mostra que a anti-retórica, nos tempos modernos, tornou-se em um dos mais importantes meios artísticos retóricos que se vale da dureza do realismo, prometendo só ele estar à altura da condição humana - aqui em sua "Estado de natureza".

A retórica é portanto uma "arte" porque é um conjunto de dificuldades com a realidade e a realidade, em nossa tradição, é basicamente pressuposta como "natureza". Em uma ambiência 
altamente artificial, tão pouco é percebido da retórico porque ela é onipresente. A figura anti-retórica clássica, "res, non verba!" portanto remete a uma estado de coisas que, por seu lado, não tem a ver com a sanção do natural senão que já com uma tintura retórica. Por outro lado, isso faz um pouco menos (ou mais) risível a recomendação enfática ou a apresentação de meios estilísticos retóricos. Isso logo é atribuído ao realismo intensificado. As dificuldades modernas da retórica com a realidade em boa parte consistem que esta realidade não mais tem valor de apelo porquanto, de sua parte, ele é resultado de processos artificiais. Assim se entra na específica situação retórica de assegurar-se a advertência para não a deixar a outros: "ad res", "para a coisas e de volta às coisas!". Ser necessário sugerir a outros o pressuposto de voltar às coisas ou, em suma, de começar a pensar e agir é retórico. Se fosse possível ver e manejar a realidade "realisticamente", ela seria sempre assim vista e manejada. A atitude de retour au réel muito mais do que com a realidade que promete tem a ver com ilusões, enganos e sedução que se tem de eliminar. Toda retórica do realismo precisa dos complôs que até agora o obstaculizaram. A alegoria da caverna, em que os prisioneiros diante do jogo de sombras da parede de fundo, nunca encontram a realidade verdadeira, a não ser que escapem violentamente, é o modelo de tal tipo de desmascaramento: é dirigida contra a retórica de que os sofistas como "artífices de imagens" são os maquinadores das sombras e ela própria é uma retórica, pois que depende da metáfora elementar da chegada à luz, ampliada na alegoria de uma realidade absoluta, cuja promessa de evidência não pode ser cumprida. A volta filosófica, em seguida estética, das sombras em realidade foi usurpada da retórica. Jean Paul reflete ironicamente por duas frases em seu romance, Unsichbaren Loge (A sociedade invisível): Uff, somos apenas sombras trêmulas! $E$, no entanto, queremos despedaçar a outra sombra? Na Crítica da faculdade de julgar, Kant declarou a retórica, como arte de servir-se das fraquezas humanas para seus propósitos, indigna de qualquer consideração. ${ }^{5}$ Esta arte astuta visa deste modo a conduzir os homens como máquinas para um certo juízo em coisas importantes. Ora, não é discutível 
que a inclinação constitutiva do homem para ações retóricas sempre é uma predisposição para o retórico; para o homem, há riscos e pressões suficientes para que ele se converta em máquina. A teoria da retórica sempre desmascarou o propósito de utilizar estas fraquezas humanas, porquanto delas se tem servido. Em uma localização antropológica da retórica, não se trata daqueles propósitos mas sim destas fraquezas. Com isso, os acessos antropológicos à retorica convergem com a verificação descritiva central: a criatura humana não tem em si algum comportamento imediato, puramente "interno". Sua autocompreensão tema estrutura da "autoexterioridade". Kant foi o primeiro a negar que a experiência interna tivesse precedência sobre a externa; somos para nós mesmos a síntese secundária, fenomênica de uma multiplicidade primária e não o contrário. O substancialismo da identidade está em pedaços; a identidade deve ser realizada, torna-se um modo de produção e a ela corresponde uma patologia da identidade. A antropologia tem tão-só por tema uma "natureza humana", que nunca foi "natureza" e nunca será. Que ela se apresente com disfarces metafóricos - como animal, como máquina. Como camadas estratificadas e como fluxo de consciência, à diferença ou em concorrência com um Deus - a antropologia não justifica a expectativa de que, no fim de todas as confissões e moralidades, essa natureza seja desvelada. O homem se compreende a si além do que não é. Não só sua situação como também sua constituição é potencialmente metafórica. O pior lugar que poderíamos escolher é em nós, formula Montaigne o resultado de sua antropologia como autoexperiência (la pire place, que nous puissions prendre, c'st en nous). ${ }^{6}$ Ele se refere à revolução copernicana que, como trauma da interioridade cósmica do homem, metaforicamente fortalece o ceticismo quanto à sua autointerioridade. Pela conduta externa, a autopersuasão subjaz a toda retórica; ela não só afeta as proposições muito gerais e praticamente eficientes, de que antes tratamos, como a autocompreensão a partir da autoexteriorização. A metáfora mais ousada, que procurava abarcar a maior tensão, talvez tenha daí provocado a autocompreensão do homem: à medida que tentava pensar o Deus como o absolutamente outro, o 
homem principiava irresistivelmente o ato retórico mais difícil: comparar-se a si mesmo com este Deus.

\section{REFERÊNCIAS BIBLIOGRÁFICAS}

BLUMENBERG, Hans. Paradigmen zu einer Metaphorologie. Archiv für Begriffsgeschichte, v. 6, p. 7-142, 1960.

KUHN, Thomas. The Structure of Scientific Revolutions. Chicago: Chicago University Press, 1962.

MARX, Karl; ENGELS, Friedrich. Marx-Engels-Werke. Band 8. Berlin: Dietz, 1960.

MEYER, Ahlrich. Mechanische und organische Metaphysik politischer Philosophie. Archiv für Begriffsgeschichte, v. 13, p. $128-199,1969$.

NIETZSCHE, Friedrich. Gesammelte Werke. Band 6. München: Musarion, 1921.

NIETZSCHE, Friedrich. Cicerofragment. In: NIETZSCHE, F. Gesammelte Werke. Band 7. München: Musarion, 1923. 